Article

\title{
Feeling Left Behind by Political Decisionmakers: Anti-Establishment Sentiment in Contemporary Democracies
}

\author{
Luigi Droste \\ Institute of Sociology, University of Münster, Germany; E-Mail: luigi.droste@uni-muenster.de
}

Submitted: 20 December 2020 | Accepted: 13 June 2021 | Published: 27 August 2021

\begin{abstract}
According to much of the extant literature, feelings and beliefs among many citizens of being left behind and unheard by unresponsive political decisionmakers, who lack moral integrity represent the epicenter of recent protest and populist discontent in democratic society. Based on survey data for 20 contemporary democracies from two ISSP waves, we found that anti-establishment attitudes are not shared among the majority of respondents. Although there are differences between country contexts. Such sentiment is associated with macrostructural dynamics, since unfavorable attitudes toward politicians are more widespread among publics in countries which are exposed to higher levels of public corruption and witnessed increasing levels of income inequality. Besides, such sentiment is also restricted to particular social groups of society, because hostile feelings toward political decisionmakers are stronger among citizens in the lower ranks of society and among younger birth cohorts. Since the beginning of the century and throughout the Great Recession, unfavorable attitudes toward politicians have not increased among the public in advanced democracies. However, our analysis indicates that respondents with such attitudes have increasingly turned toward voting for anti-elite parties to raise their voice and now make use of online options to express their political views more frequently than in the past. Overall, the analysis contributes to recent research on populist and reactionist dynamics in contemporary democracies by addressing dynamics and structures of the feeling of being left behind by political decisionmakers and its implications for political (in)activity.
\end{abstract}

\section{Keywords}

anti-elitism; anti-establishment sentiment; democratic discontent; ISSP; political participation; populist attitudes

\section{Issue}

This article is part of the issue "Reactionary Politics and Resentful Affect in Populist Times" edited by Tereza Capelos (University of Birmingham, UK), Stavroula Chrona (King's College London, UK), Mikko Salmela (University of Helsinki, Finland / University of Copenhagen, Denmark), and Cristiano Bee (Oxford Brookes University, UK).

(C) 2021 by the author; licensee Cogitatio (Lisbon, Portugal). This article is licensed under a Creative Commons Attribution 4.0 International License (CC BY).

\section{Introduction}

As Mair (2013, p. 19) observes: "The political class has become a matter of contention." Nowadays, democracies all over the world seem to be confronted with the phenomenon of a widening gap between citizens and their elected representatives. Discourses and worldviews which pit "ordinary people" against "self-serving" and "morally corrupted" elites in a stylized friendfoe dichotomy, have recently gained salience. Many observers emphasize not only a withdrawal of citizens from conventional political life, but also increasing contempt for political elites. Next to rising levels of voting abstention, the decline of established political parties and an overall erosion of "politics as usual," we are witnessing two other trends: the rise of populist parties and the rise of popular protest movements. According to much of the literature, such parties and movements appeal to people who are discontented with the political mainstream, who may share the feeling of being unrepresented by political authorities and disconnected from official decisionmakers. Mudde and Kaltwasser (2017, p. 51) note: "Populist political parties use populism to challenge the establishment and to give voice to groups that feel unrepresented."

While research has engaged in studying the changing role of political parties for voters, citizens' political apathy and the sympathizers of populist move- 
ments, we know far less about how citizens' feelings and attitudes toward political elites look like, how they vary socially and how they shape political behavior. A look at the extant literature elucidates that structures, variations, and implications of such an antiestablishment sentiment in contemporary democracy needs further research.

Anti-establishment sentiment is a phrase borrowed from the everyday language of politics (in private talk or media coverage) and is typically adopted in scientific articles without any clear definition as an ad hoc semantic. Anti-establishment sentiment as a political attitude is conceptualized here as a component of populist attitudes. So-called populist attitudes are commonly perceived as a multidimensional and morality-based construct comprising (1) anti-establishment attitudes next to (2) a Manichean outlook on society and (3) belief in popular sovereignty (Akkerman et al., 2014; Mudde, 2004). While anti-establishment sentiment can generally refer to a conglomerate of very different groups of political, economic, intellectual, and cultural elites, we are only interested in discontent with political elites. In the literature on populist attitudes, anti-establishment attitudes are indeed typically equated with negative attitudes toward the political establishment. Thus, when we speak of anti-establishment sentiment or anti-establishment attitudes, we do this with reference to political elites. If we define attitudes as a "psychological tendency, expressed by evaluating a particular entity with some degree or favor or disfavor" (Eagly \& Chaiken, 1993, p. 1), anti-establishment attitudes are negative and unfavorable evaluations of political representatives. To be more specific, anti-establishment attitudes are a set of "feelings of marginalization" (Oliver \& Rahn, 2016) relative to political power and beliefs of being unheard and unrepresented by political elites who are perceived as morally corrupt, self-serving, and who are depriving voters of their legitimate voice. Hence, on the one hand, the concept comprises feelings of external political efficacy which refer to more generalized and affectively charged beliefs about politicians' responsiveness to citizens' demands (Niemi et al., 1991). On the other hand, it refers to beliefs that politicians lack moral integrity (Akkerman et al., 2014). In public opinion literature, anti-establishment orientations have been for long examined under the rubrics of political cynicism (Agger et al., 1961; Rooduijn et al., 2017), political efficacy (Niemi et al., 1991), political trust (Citrin \& Stocker, 2018) or political support (Easton, 1975). More recently, attitudes toward the political establishment have been included in concepts, such as political disaffection (Torcal \& Montero, 2006) and populist attitudes (Akkerman et al., 2014; Kaltwasser \& Van Hauwaert, 2020). Although "anti-establishmentness" is not an exclusive feature of populist attitudes, the view that political elites are self-serving, morally corrupt and disinterested in the "average man" is at the heart of populism (Mudde, 2004).
Surprisingly, previous research has either explored anti-establishment attitudes as a component of a broader concept, as in the cases of populist attitudes and political cynicism, or it has been operationalized via one single indicator, namely trust in politicians (Noordzij et al., 2019). The analysis based on data from the General Social Survey (GSS), offered by Rahn (2019), represents a notable exception in dealing with so-called anti-elite attitudes in the United States and their effect on voting for Donald Trump. However, it should be noted that Rahn herself did not provide any definition of her concept of anti-elite attitudes.

Against this backdrop, extent and social basis of anti-establishment sentiment still remain a lacunaparticularly when it comes to cross-country research. Besides, whereas anti-elitism and trust in politicians have been studied as predictors of populist voting (Rooduijn, 2018) or protest behavior (Grasso et al., 2019; van Stekelenburg \& Klandermans, 2013), it remains unclear whether hostility toward political elites became over time more important for participation in political life or not. Therefore, this article intends to find out (1) how widespread anti-establishment attitudes are among the electorate, (2) who feels left behind by political decisionmakers, (3) how anti-establishment attitudes are linked to macrostructural dynamics, and (4) whether those who feel left behind by political authorities have become politically more active than before by raising their voice in elections, on the web or in the streets. The analysis of hostile attitudes toward politicians is relevant for finer-granulated research on populist mindsets, reactionary attitudes, and convictions of (non-)voters and protesters. This is in particular the case, since beliefs of being unheard by political decisionmakers can give rise to affects like resentment and can constitute a part of ressentiment that guides political action in populist times (Capelos \& Demertzis, 2018; Capelos \& Katsanidou, 2018; Salmela \& Capelos, 2021; Salmela \& von Scheve, 2017).

\section{Anti-Establishment Attitudes: Prevalence, Social Correlates, and Political Repercussions}

The rising success of populist parties in elections across the world suggests that hostile feelings toward political decisionmakers are generally widespread among voters. Populist parties characteristically draw on a rhetoric that emphasizes the distance and estrangement between ordinary citizens and the political establishment. Also, prominent protest movements which have formed since the global financial crisis of 2008 in various national contexts hint at widespread discontent with the "political class," as such movements typically confront established parties and politicians with ignored demands from below. Next to such empirical reasons for proposing the virulence of anti-establishment attitudes, there are theoretical accounts. Mudde's (2004) diagnosis of a "populist zeitgeist" suggests that today populist discourse has become a mainstream phenomenon in politics in 
advanced democracies. The outrage over established political representatives represents a central part of such a populist zeitgeist. Inglehart (1977) takes on another perspective according to which postmodern societies witnessed a "cognitive mobilization" throughout the last decades, meaning that societal modernization triggered critical views toward political authorities (see also Dalton \& Welzel, 2014). Such a view is echoed in more recent accounts which postulate the "deconsolidation" (Foa \& Mounk, 2017) or even the "end" (Levitsky \& Ziblatt, 2018) of democracy in face of decreasing levels of support for democratic institutions. Against this backdrop, we expect that anti-establishment attitudes should be relatively widespread among the public ("antiestablishment zeitgeist" thesis).

Recent discussions on political discontent suggest two popular individual-level explanations for the prevalence of anti-establishment sentiment: socio-economic status and generational change. First, a growing body of research confirms that parties and governments respond unequally to different social status groups. For the United States, Gilens (2012) documents selective responsiveness on the part of political decisionmakers, in favor of affluent citizens. He finds that political decisions only reflect lower status citizens' opinions if these coincide with the preferences and opinions of affluent citizens. Low and even middle-income groups seem to have no political influence once their preferences diverge from those of top income groups. Studies on European countries corroborate these findings (Elsässer et al., 2020; Schakel, 2019). Explanations for this phenomenon vary from interest-group lobbying (Gilens, 2012) to political participation (Gallego, 2014) or descriptive representation (Bovens \& Wille, 2017). As studies on perceived responsiveness demonstrate, actual responsiveness is indeed mirrored in perceived responsiveness. In a recent comparative analysis, Lindh and McCall (2020) show that in nearly all countries under analysis workers perceive the government as less responsive than members of the middle and upper classes. As a consequence, it is supposed that perceived unresponsiveness gives birth to anti-establishment attitudes, as a rational and an emotional reaction. Second, there is support for the idea that a generational change is afoot and is the influence of shrinking support for democratic values and decreasing institutional trust in Western democracies (Dalton, 2004, 2005). As research shows, the young tend to be less trusting of government and are less invested in democracy than their elder counterparts (Citrin \& Stocker, 2018; Foa \& Mounk, 2017). Whereas this is interpreted as a form of emancipation and the emergence of more "critical" or more "assertive" citizens by some authors (Dalton \& Welzel, 2014; see Inglehart, 1977), others claim that generational change is bringing about democratic deconsolidation (Foa \& Mounk, 2017). In face of existing accounts on unequal responsiveness and assertive citizens, we expect that lower classes ("unresponsiveness" thesis) and younger birth cohorts ("critical citizens" thesis) should exhibit stronger antiestablishment attitudes.

In addition to individual-level variation, perceptions of political elites likely are conditioned by national contexts and macrostructural processes. However, most of the extant literature on political discontent has either dealt with investigations at the individual or the aggregate level. As a consequence, multilevel designs remain largely absent. Furthermore, while previous research on the contextual determinants of democratic discontent has relied on cross-sectional evidence and between country effects, dynamics in contextual factors are often overlooked. Although the literature on political discontent has uncovered a broader set of macrostructural explanations, we will focus on three popular accounts: economic inequality, public corruption, and economic affluence.

Economic affluence and socio-economic conditions are likely to shape popular perceptions of the functioning of democratic institutions and their legitimacy in general and therefore provide a fertile terrain for democratic consolidation (Inglehart, 1977; "affluence" thesis). However, it is also reasonable that it is not economic affluence as such but rather the distribution of economic affluence that matters for feelings and attitudes toward democratic institutions and its personnel (Anderson \& Singer, 2008; Schäfer, 2012). According to the Schattschneider's (1960) hypothesis, those with more economic resources are able to eliminate policy alternatives from the political agenda beneficial to the lower and middle classes. As a consequence, those in the lower and middle classes will begin to believe that political decisionmakers are no longer responsive to their political interests ("inequality" thesis). In addition to economic affluence and its distribution, anti-establishment sentiment is likely to be rooted in objective misconduct of politicians and whether political authorities play by the rules. A study by Anderson and Tverdova (2003) indicates that trust in government is negatively related to the actual level of corruption. Consequently, we expect that anti-establishment attitudes should be enhanced through actually observable missing integrity of political decisionmakers ("objective misconduct" thesis).

Have those who feel unrepresented by political decisionmakers become politically more or less active over time? On the one hand, anti-establishment attitudes make up a sentiment that potentially inspires political engagement. According to literature on populist voting, discontented citizens experience political fulfillment through voting for a party that voices their discontent, regardless of whether discontents are "expressed" or (also) "fueled" (Rooduijn et al., 2016). Indeed, populist voting seems to be driven in large parts by political disaffection and perceived unresponsiveness (Ferrari, 2021; Rooduijn, 2018). Participation in unconventional forms of political protest is also more likely for citizens who have lost faith in politicians and public officials (Gallego, 2014; Grasso et al., 2019; van Stekelenburg 
\& Klandermans, 2013). While earlier research on political action has addressed protest activities such as non-voting or taking part in demonstrations, more recent accounts additionally emphasize positing political opinions online on the web (Rensmann, 2017; Zukin et al., 2006) and voting for outsider or challenger parties (Inglehart \& Norris, 2019). Citizens may choose "voice" (as in voting for so-called anti-elite parties or joining protests) to express their discontent. This "voice" option might be based on pure protest motives and on perceptions of responsiveness because populist parties and candidates often politicize issues which were previously not debated. Unfavorable perceptions of political elites are embedded in emotional states of anger (Rico et al., 2017), resentment, and ressentiment (Capelos \& Demertzis, 2018; Salmela \& Capelos, 2021; Salmela \& von Scheve, 2017). In particularly, anger and resentment have previously been found to boost political action (Capelos \& Demertzis, 2018). Anti-establishment attitudes are also of moralized character because political elites are perceived as self-serving and morally corrupt. Since previous research reveals that morality increases the motivation to become politically active (Skitka \& Bauman, 2008), a morality-based rejection of political decisionmakers might create a legitimized justification for personal engagement. As Anduiza et al. (2019) show, political attitudes which comprise an anti-elitism component tend to have a positive effect on political engagement. On the other hand, anti-establishment attitudes might make citizens choose "exit" (as in abstention) and thereby spur withdrawal from political life. As a study by Capelos and Demertzis (2018) shows, political discontent as manifested in ressentiment can lead to so-called "dormant support" if it combines with perception of self-efficacy. Thus, such a withdrawal may either be performed as a form of "meaningful political agency" (Kemmers, 2017, p. 391) or simply as a consequence of missing viable "voice" options, i.e., opportunity structures for articulating political discontent. However, throughout the last two decades viable "voice" options have increased in contemporary democracies. Either in the form of the rise of populist challenger parties (Inglehart \& Norris, 2019), the spread of protest movements (Grasso et al., 2019), or the increasing role of social media and digital publics (Rensmann, 2017). According to the literature, the success of populist anti-elite parties and movements appears to be fueled by the mobilization of politically alienated citizens who have a strong propensity to support populist actors, because their populist discourse articulates citizens' discontent with the political mainstream (Gidron \& Hall, 2020; Mudde \& Kaltwasser, 2017; Rooduijn et al., 2016, 2017). Via options to visibly articulate discontent, populist movements and parties are able to mobilize excluded segments of society which have previously felt unrepresented and left behind by the established political personnel. In face of populist parties' electoral wins since the Great Recession, the rise of new street protest movements and the emergence of an angry political web culture, we expect that increased "voice" opportunities have strongly gathered support among citizens who feel left behind and betrayed by political decisionmakers ("increasing engagement" thesis).

\section{Data and Methods}

\subsection{Data}

We use data from the International Social Survey Program (ISSP) for our analysis. In 2004 (field period: 2003-2006) and 2014 (field period: 2013-2016), the ISSP contained a "citizenship" module, which asked respondents about their attitudes and feelings toward politicians (ISSP Research Group, 2012, 2016). For the analysis, the number of countries decreases to 20 because some countries did not participate in both waves and for others important items are missing. The final dataset is therefore a panel study on the country-level, but with different individuals in each wave. It covers a set of developed democracies: Australia, Austria, Belgium, Switzerland, Czech Republic, Germany, Denmark, Finland, France, Israel, Japan, South Korea, the Netherlands, Norway, Poland, Slovakia, Slovenia, Spain, Sweden, and the United States.

\subsection{Variables and Analytical Design}

In a first step, we explore anti-establishment attitudes and how differences therein can be explained. We operationalize anti-establishment attitudes on the basis of five items which tap into citizens' attitudes toward political decisionmakers (see Table A1 in the Supplementary File for exact wordings). The items indicate (1) to what extent respondents think that the government does not care much about ordinary people, (2) to what extent respondents think that politicians cannot be trusted, (3) to what extent respondents think that politicians are only self-serving, (4) to what extent respondents think that government officials are committed to serve the people, and (5) whether respondents think corruption is widespread among government officials. Following Rahn (2019), we recode the items and construct a scale with a 0-1 range with higher values indicating more hostile feelings and attitudes toward political elites (cross-country Cronbach's Alphas reach 0.71 and 0.74 respectively).

The investigation into anti-establishment attitudes relies on a multilevel hybrid model that nests people in years, which are in turn nested in countries. This approach uses individual-level data and allows the decomposition of country-level effects into a "between" (cross-sectional) and a "within" (longitudinal) components, while simultaneously controlling for compositional effects from the individual level (Fairbrother, 2014).

In a second step, we analyze whether antiestablishment attitudes correlated with different forms of political participation and how this has changed over 
time. We choose to distinguish between rather "conventional" forms of political action including (1) abstaining from voting and (2) voting for an anti-elite party next to so-called "unconventional" political action in form of (3) taking part in demonstrations and street protests and (4) expressing political views on the internet (on such a distinction see, e.g., Barnes \& Kaase, 1979; Capelos \& Demertzis, 2018). Taking part in demonstrations, expressing political views on the internet and abstain from voting are coded as dummy variables with a value of 1 (otherwise 0 ) if respondents have participated in a demonstration, or have posted something political on the internet in the past year, or did not vote in the country's last national election. By anti-elite parties we mean parties which Abedi (2004) defines as "antipolitical-establishment parties" and which (1) perceive themselves as challengers to the parties that make up the political establishment, (2) emphasize a fundamental divide between the political establishment and the people, and (3) challenge the status quo in terms of major political issues. Against this backdrop, we operationalize voting for an anti-elite party by relying on an indicator derived from the Chapel Hill Expert Survey (CHES) which measures the salience of anti-elite rhetoric for political parties based on expert rankings (Bakker et al., 2020). The salience score ranges from 0 (low) to 10 (high). Unfortunately, the measure is only available for a set of European countries, this restricts our analysis on voting decisions to a number of 12 European countries. Therefore, we refrain from multilevel modelling in the analysis of political participation and rely on simple regression models with country and time fixed effects.

We operationalize objective social status via a respondent's location within the labor market with the class schema based on Oesch (2013). Such a categorization leads to an eight-class schema which distinguishes between: (1) managers, (2) sociocultural professionals, (3) technical specialists, (4) large employers, (5) small business owners, (6) clerks, (7) production workers, and (8) service workers. For the analysis, we slightly diverge from the original schema and pooled managers and large employers so that we use a seven-class schema. We measure generational differences by distinguishing between 5 birth cohorts (1925-1940: inter war generation, 1940-1955: 68ers, 1955-1970: babyboomers, 1970-1985: generation X, 1985-2000: generation Y).

As controls, we use subjective social status, measured by a question asking respondents to place themselves on a 10-point social ladder reflecting their position in society. For the highest schoolleaving certification, we make use of the International Standard Classification of Education (ISCED) and create four categories: (1) low (no formal qualification/lower secondary education), (2) medium (middle secondary education), (3) higher medium (higher secondary education), and (4) high (tertiary education/university degree). Respondents' interest in politics is measured on a 4-point disapproval scale, whereas respondents' self-perceived political under- standing is reported on a 4-point approval scale. A variable covering the political self-placement on a left-right scale has only been asked in the second wave of the ISSP citizenship module (2013-2016) so that we have to exclude this item from our analysis. The models also control for family income and the number of persons living in the household. Because the ISSP includes family income in country specific values, each income value is standardized relative to the country's mean income. We also control for gender (dummy variable: male/female) and region (dummy variable: urban/rural).

In the multilevel analysis, we consider three explanatory factors on the country level: economic inequality, national economic affluence, and the level of public corruption. Inequality is operationalized by the Gini index, which measures the extent to which the distribution of income among individuals or households deviates from a perfectly equal distribution (SWIID, 2021). It can range from 0 (perfect equality) to 100 (perfect inequality). Affluence is measured by GDP per capita (PPP, in $\$ 1,000$ US; OECD, 2021). As a measure for corruption, we rely on the $\mathrm{CPI}$ (Corruption Perception Index) which ranks countries based on how corrupt their public sector is perceived by experts (Transparency International, 2021). Note that the CPI ranges in value from 0 (highly corrupt) to 10 (absolutely clean from corruption). The selected indicators always refer to the year before the ISSP fieldwork year.

\section{Findings}

How widespread are negative attitudes toward political decisionmakers in contemporary democracies? Visual inspection of the distribution of the scale of antiestablishment attitudes shows it to be normally distributed. In both survey waves, around $16 \%$ of the respondents express strong anti-establishment attitudes, as indicated by values in the highest quartile on the scale (Figure 1). However, nearly $80 \%$ of all respondents are grouped in both quartiles in the middle of the scale. This indicates that contemporary democracies are neither polarized by negative feelings toward politicians, nor can we speak of widespread anti-establishment sentiment which manifests itself in an "anti-establishment zeitgeist." The results are not indicative of a so-called "silent majority," which is marked by strong feelings of political discontent. Our findings align with empirical research (van Ham et al., 2017) that does not offer backup for the diagnosis of "democratic deconsolidation" in advanced democracies, since the great majority still supports democratic norms and institutions.

As the literature on democratic support indicates, there are cross-country differences in legitimacy beliefs, trust levels and sentiments (Martini \& Quaranta, 2020). This is confirmed by our findings on anti-establishment sentiment. Figure 2 shows the prevalence and temporal development of anti-establishment sentiment among the 20 democracies, as measured using our 

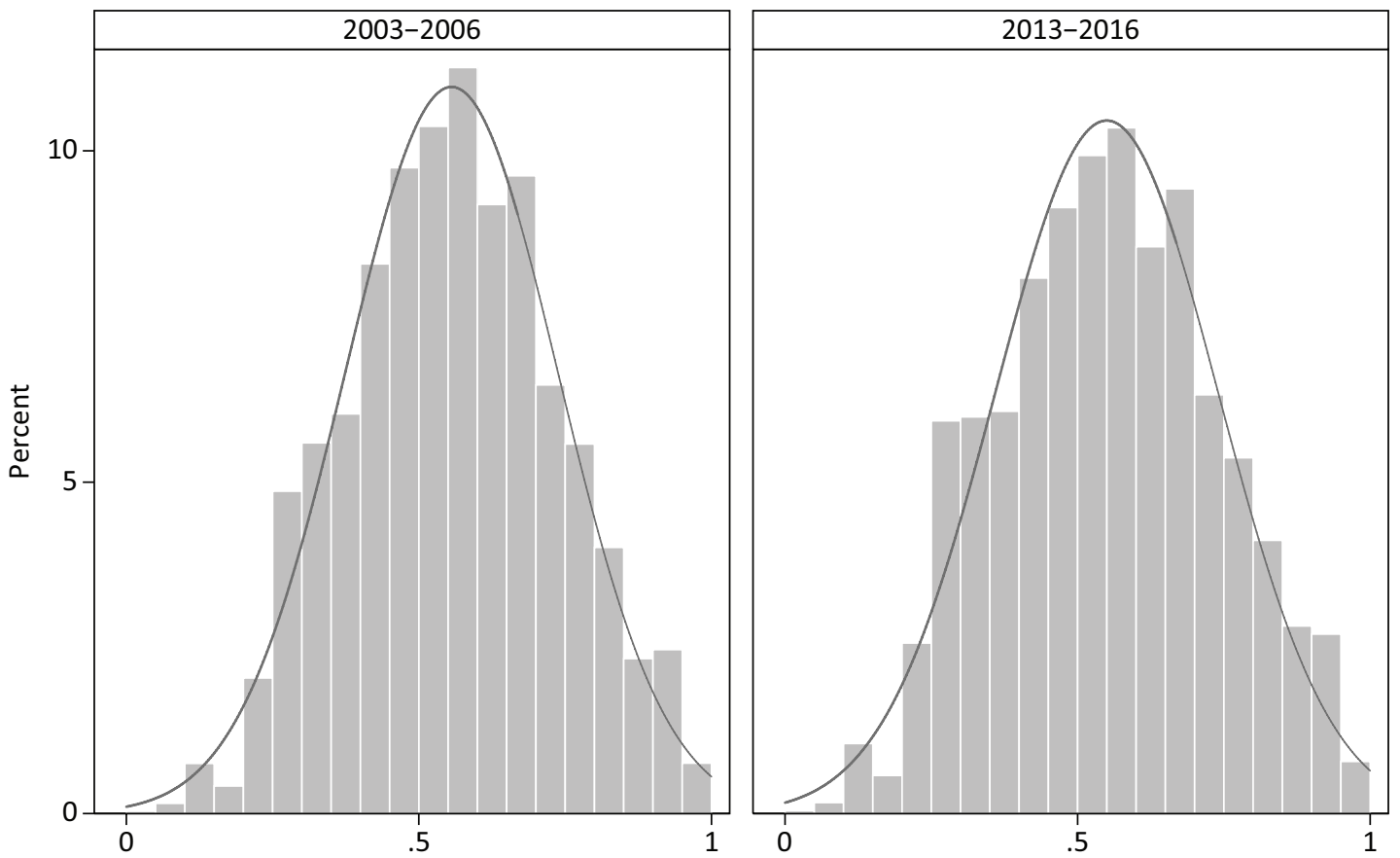

Anti-establishment sentiment

Figure 1. Distribution of anti-establishment attitudes. Source: ISSP Research Group (2012, 2016, weighted).

anti-establishment attitudes scale. Whereas average anti-establishment attitudes remained relatively stable in some cases (Finland, Australia, Austria, Czech Republic) or strongly decreased in some (Norway,
Germany, Sweden), it strongly increased in others (United States, Spain, Slovenia). However, the overall means for both survey waves are nearly identical (0.556 for wave 1 and 0.552 for wave 2). Although

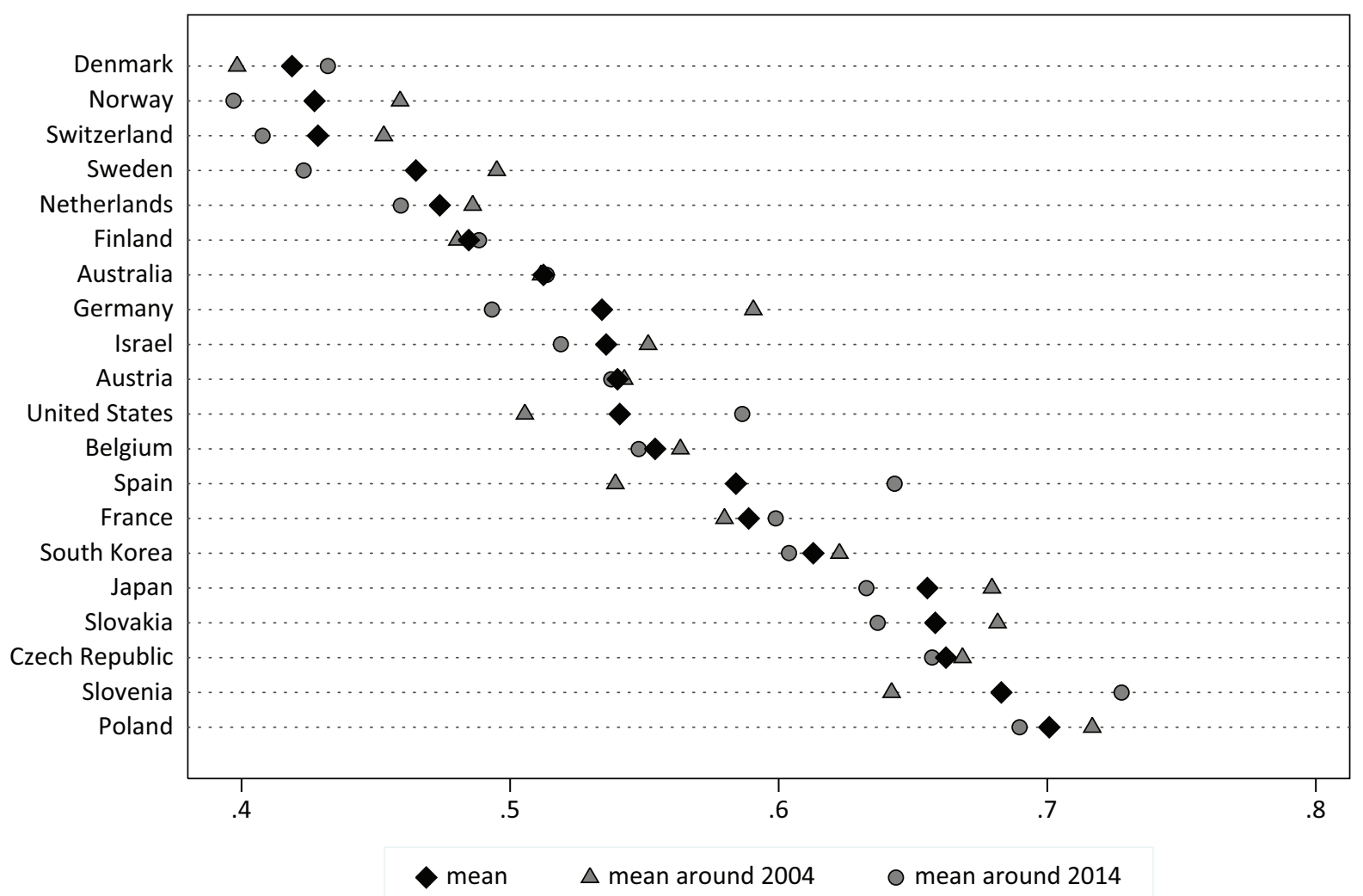

Figure 2. Mean values of anti-establishment attitudes, by wave and country. Source: ISSP Research Group (2012, 2016, weighted). 
there are some fluctuations at the country-level, antiestablishment attitudes have neither increased uniformly among publics nor have they exploded since the beginning of the century and throughout the years of the Great Recession.

How is anti-establishment sentiment distributed among different social groups, and which contextual conditions favor beliefs that the political personnel is alienated from their voters? The coefficient plots in Figure 3 and 4 show results from hierarchical linear multilevel regressions which nest individuals ( $N=33,246$; level 1 ) in 40 country-years (level 2), which are nested in 20 countries (level 3; for detailed information see Table A2 in the Supplementary File). The intraclass coefficient in the empty model (Model 0 ) indicates that most of the variance in anti-establishment sentiment is located at the individual level. However, there is also a considerable amount of variance between countries (19.9\%) and between survey waves (23.5\%).

At the individual level, results reveal that social class and birth cohort membership matter for antiestablishment attitudes. We can find a clear classgradient which confirms the class-based "unresponsiveness" thesis. Anti-establishment attitudes are stronger among production workers in contrast to managers. There are also significant differences between service workers, clerks and technical professionals in contrast to the manager class, albeit to a lower degree. No significant differences in anti-establishment attitudes exist between managers and sociocultural professionals. Thus, by large and as expected from the literature, the differences between social classes in anti-establishment attitudes support the idea that actual unequal government responsiveness goes hand in hand with perceived unresponsiveness. However, such an explanation is not necessarily true. A lower status position could also give rise to complex feelings of ressentiment and denied social recognition which can find expression in scapegoating or assigning responsibility to external "enemies." With political decisionmakers representing only one of those "enemies" among others (see Ferrari, 2021; Salmela \& von Scheve, 2017). Besides, the strong anti-establishment sentiment among self-employed as compared to managers remains in need of an explanation. This result could be interpreted as a sign of the alienation of specific parts of the middle classes from the political process, albeit we should be careful with this, because the group of the self-employed is very heterogenous. As expected above, the analysis documents statistically significant differences between birth cohorts. In contrast to the youngest birth cohort, older birth cohorts are more positive about the political personnel. There is, however, no statistically significant difference between the youngest birth cohort (1985-2000) and the cohort born between 1970 and 1985. When it comes to attitudes toward political elites, there seems to exist a generational gap which separates people born after 1970 from the ones born before.

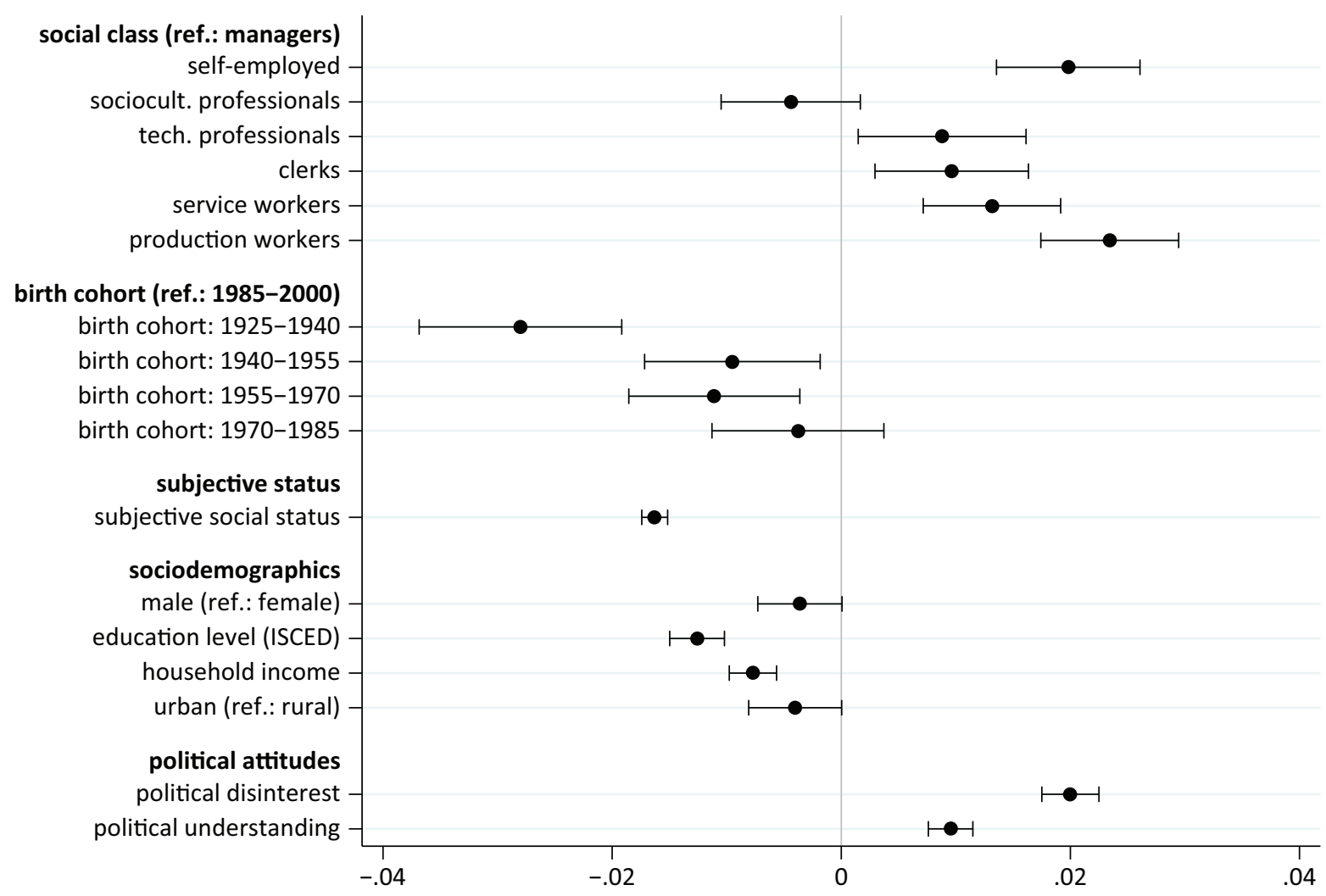

Figure 3. Coefficient plot for the individual level. Note: Point estimates and $95 \%$ confidence intervals are based on Model M2 in Table A2 in the Supplementary File. Source: ISSP Research Group $(2012,2016)$. 


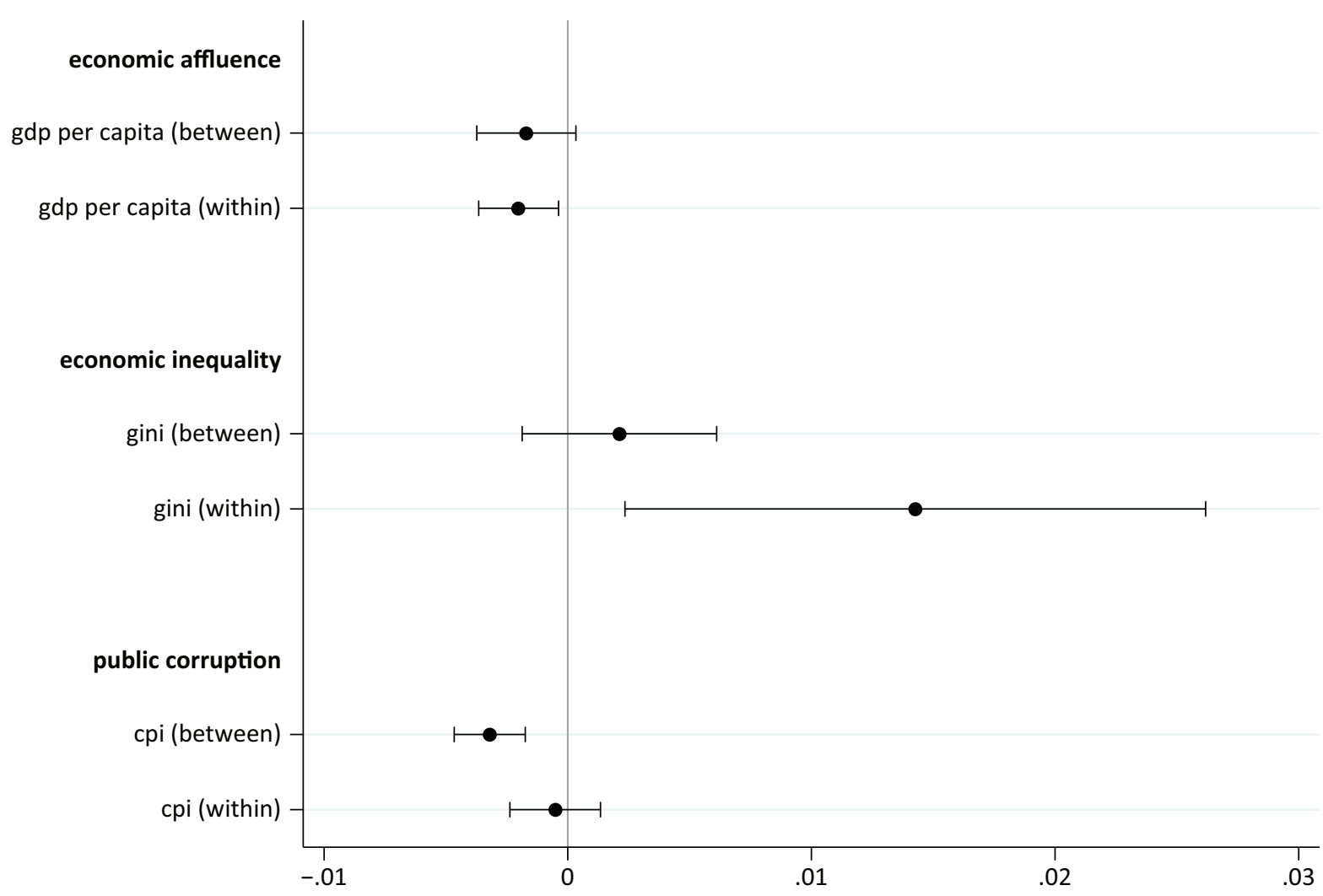

Figure 4. Coefficient plot for the contextual level. Note: Point estimates and $95 \%$ confidence intervals are based on Model M2 in Table A2 in the Supplementary File. Source: ISSP Research Group $(2012,2016)$.

Such findings support accounts which emphasize the rise of elite-challenging sentiments among younger generations and are congruent with the cohort-based "critical citizens" thesis (Dalton \& Welzel, 2014; Foa \& Mounk, 2017). Nevertheless, it remains unclear whether this is driven by value change, intergenerational social downward mobility or resentment, which is rooted in the participation within digital publics among younger generations. The control variables show that respondents feel unrepresented by political decisionmakers to a larger extent, when they place themselves in the lower ranks of the social ladder, earn less, have lower levels of education, live in rural regions, are politically disinterested, and perceive themselves as competent and knowledgeable in political issues.

At the contextual level, we find a positive and statistically significant relationship between income inequality and citizens' attitudes toward politicians. However, this relationship is driven by within-country differences, i.e., differences between survey years, whereas levels in societal income inequality between countries do not explain differences in citizens' anti-establishment sentiment. Thus, people exhibit more hostile attitudes toward politicians in those years where more inequality exists in their country than what exists during an average year (within-country effect). We also discover a negative and statistically significant association between economic affluence and citizens' perception of politicians. This relationship is also driven by within-country differ- ences. Thus, it is more the dynamics of affluence which matter for discontent with the political establishment than its actual level. Not surprisingly then, on average, economic downturns are associated with hostile feelings toward political decisionmakers. Results further suggest that, all else equal, citizens living in a country where corruption in the public sector is widespread, have a more negative opinion of politicians compared to those living in a less corrupt society. In contrast, within country dynamics in public corruption do not matter. In other words, knowing the level of corruption in a country, relative to other countries, gives us purchase on their beliefs about the responsiveness and moral integrity of their political authorities. Knowing how corruption prevalence in a given society has changed between survey waves, however, does not help to explain citizens' anti-establishment sentiment. Thus, whereas contextual dynamics are important when it comes to inequality and affluence, levels are decisive when it comes to official misconduct by political decisionmakers. Yet, note that we have to interpret the contextual effects with caution, since the number of countries $(N=20)$ in the analysis is rather small.

Are anti-establishment attitudes related to active political participation, or rather to a withdrawal from political life? Due to limited space and because we are mainly interested in the association between antiestablishment attitudes and different forms of political participation, we leave other variables undiscussed. 
Table 1 shows that, net of controls, respondents who score higher on the anti-establishment attitudes scale are more likely (1) to abstain from voting in national elections, (2) to take part in street protests, and (3) to post and discuss political issues on the internet. Besides, and not very surprising, (4) respondents with stronger negative feelings toward politicians also vote for parties which criticize the political elite and emphasize the aloofness of the political personnel more strongly. Therefore, antiestablishment attitudes correlate with both: active political participation and withdrawal from political life. This finding suggests that although some citizens share the same kind of attitudes toward political decisionmakers, the articulations of such attitudes are far from homogenous. Indeed, as qualitative evidence suggests, the chosen form of political action depends on citizens' power orientation which consists of the (implicit) definitions of the situation with regard to where political power is located and who the main actors who possess power are (Kemmers, 2017). Accordingly, we should be careful about speaking of "the discontented citizens," since their discontent finds different political expressions and seems to be embedded in different understandings of the concept of democracy and contradictory expectations toward political representation (Celis et al., 2021; Sullivan, 2021).

But have the associations between antiestablishment attitudes and political action perhaps changed over time? Figure 5 displays the predicted probabilities (the average of the predicted probability for all respondents in the analysis) of political participation for different levels of anti-establishment sentiment over time (see Table A3 in the Supplementary File for detailed information). Looking at all types of political activity, we see again that anti-establishment attitudes are a good predictor in all cases of political action. However, the predicted probabilities indicate that anti-establishment attitudes are a much more important predictor of voting abstention and taking part in demonstrations or street protest around 2004 compared to the years around 2014. It should be noted that the difference for voting abstention is no longer statistically significant for respondents who score very high on the anti-establishment attitudes scale. In contrast, we can observe a different pattern for online posts and voting for anti-elite parties. Around 2014, anti-establishment attitudes substantially affected

Table 1. Regression estimates of the effect of anti-establishment attitudes on types of political participation.

\begin{tabular}{|c|c|c|c|c|c|c|c|c|}
\hline & \multicolumn{2}{|r|}{ M1 } & & \multicolumn{2}{|c|}{ M3 } & \multicolumn{2}{|c|}{ M4 } \\
\hline & \multicolumn{2}{|c|}{$\begin{array}{c}\text { abstain from voting } \\
\text { in national } \\
\text { elections }\end{array}$} & \multicolumn{2}{|c|}{$\begin{array}{l}\text { taking part in } \\
\text { demonstrations } \\
\text { and street protests }\end{array}$} & \multicolumn{2}{|c|}{$\begin{array}{l}\text { posting political } \\
\text { opinions on the } \\
\text { internet }\end{array}$} & \multicolumn{2}{|c|}{$\begin{array}{l}\text { voting for } \\
\text { anti-elite } \\
\text { parties }\end{array}$} \\
\hline & $A M E$ & $p$ & $A M E$ & $p$ & $A M E$ & $p$ & Coef. & $p$ \\
\hline Anti-establishment sentiment & .137 & $* * *$ & .030 & $* *$ & .055 & $* * *$ & 1.975 & $* * *$ \\
\hline Male (Reference: female) & .023 & $* * *$ & -.000 & & .009 & $* *$ & .131 & $* * *$ \\
\hline \multicolumn{9}{|c|}{ Birth cohort (reference: 1985-2000) } \\
\hline Birth cohort: 1925-1940 & -.187 & $* * *$ & -.078 & $* * *$ & -.127 & $* * *$ & -.284 & $* * *$ \\
\hline Birth cohort: 1940-1955 & -.182 & $* * *$ & -.052 & $* * *$ & -.105 & $* * *$ & -.218 & $* *$ \\
\hline Birth cohort: 1955-1970 & -.134 & $* * *$ & -.034 & $* * *$ & -.078 & $* * *$ & -.074 & \\
\hline Birth cohort: 1970-1985 & -.074 & $* * *$ & -.034 & $* * *$ & -.045 & $* * *$ & .029 & \\
\hline Urban & .015 & $* *$ & .021 & $* * *$ & .009 & $* *$ & -.060 & \\
\hline \multicolumn{9}{|c|}{ Occupation (Reference: managers) } \\
\hline Self-employed & .004 & & -.001 & & .007 & & .068 & \\
\hline Sociocultural professionals & -.002 & & .029 & $* * *$ & 007 & & .139 & $*$ \\
\hline Technical professionals & -.001 & & .002 & & .005 & & .137 & $*$ \\
\hline Clerks & .007 & & -.007 & & -.001 & & .123 & $*$ \\
\hline Service workers & .034 & $* * *$ & .006 & & -.001 & & .323 & $* * *$ \\
\hline Production workers & .032 & $* * *$ & .002 & & -.008 & & .273 & $* * *$ \\
\hline Household income & -.016 & $* * *$ & -.002 & & -.002 & & -.102 & $* * *$ \\
\hline Education level (ISCED) & -.013 & $* * *$ & .007 & $* * *$ & .012 & $* * *$ & -.034 & \\
\hline Subjective social status & -.008 & $* * *$ & -.002 & $*$ & -.001 & & -.038 & $* * *$ \\
\hline Political disinterest & .057 & $* * *$ & -.031 & $* * *$ & -.043 & $* * *$ & -.116 & $* * *$ \\
\hline Perceived political knowledge & -.012 & $* * *$ & .005 & $* * *$ & .010 & $* * *$ & .033 & \\
\hline wave 2 (Reference: wave 1) & \multicolumn{2}{|c|}{$-.044 * * *$} & \multicolumn{2}{|c|}{$-.026 * * *$} & \multicolumn{2}{|c|}{$.038 * * *$} & \multicolumn{2}{|c|}{$.386 * * *$} \\
\hline Country dummies & \multicolumn{2}{|r|}{ yes } & \multicolumn{2}{|r|}{ yes } & \multicolumn{2}{|c|}{ yes } & \multicolumn{2}{|c|}{ yes } \\
\hline Adj. pseudo $\mathrm{R}^{2}$ & \multicolumn{2}{|r|}{.190} & \multicolumn{2}{|c|}{.156} & \multicolumn{2}{|c|}{.169} & \multicolumn{2}{|c|}{.196} \\
\hline $\mathrm{N}$ & \multicolumn{2}{|c|}{31,034} & \multicolumn{2}{|c|}{32,789} & \multicolumn{2}{|c|}{32,515} & \multicolumn{2}{|c|}{16,735} \\
\hline
\end{tabular}

Notes: ${ }^{* *} p<0.001 ; * * p<0.01 ; * p<0.05$. Source: ISSP Research Group $(2012,2016)$. 

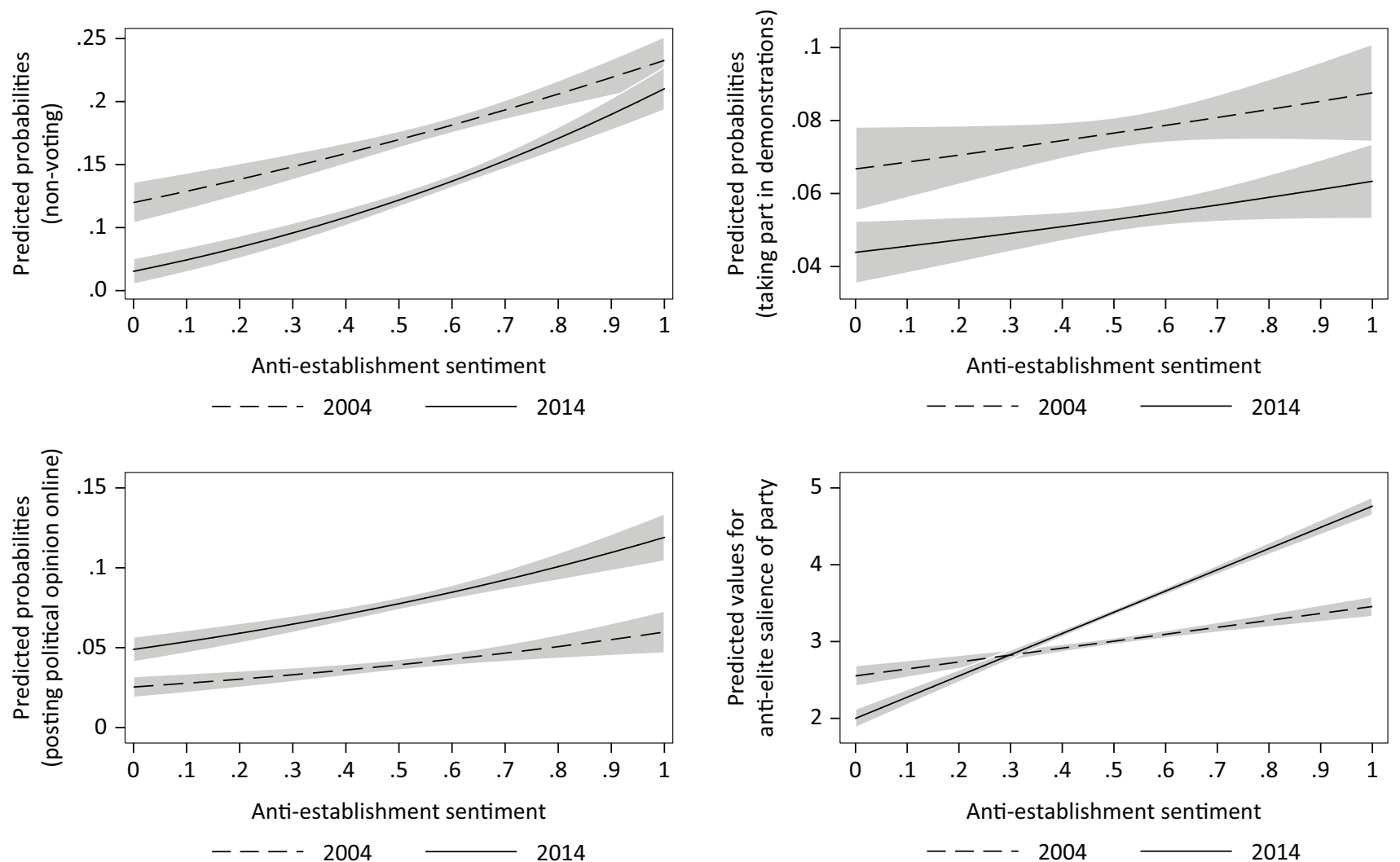

Figure 5. Predicted probabilities for anti-establishment attitudes on different types of political participation over time. Source: ISSP Research Group (2012, 2016).

the likelihood of politically motivated online activity, especially for high levels of anti-establishment attitudes, while this does not hold true for 2004. When it comes to voting for anti-elite parties, the plot in the bottom right corner of Figure 5 demonstrates the strength of the substantive effect of anti-establishment attitudes. The predicted effect sizes indicate that respondents who strongly feel left behind and unheard by political decisionmakers have increasingly turned toward anti-elite parties in national elections over time. Respondents with strong hostile feelings toward political officials vote for parties which on average score up to 2 points higher on the CHES-anti-elite salience scale in 2014 as compared to the years around 2004. All in all, thus, our "increasing engagement" thesis is only partly confirmed, since it is limited to posting political opinion online and supporting anti-elite parties. What is the main take-away of our analysis? The results of the interaction plots (Figure 5) point out that something has happened. The different effect sizes for the different waves could be interpreted as a consequence of changed opportunity structures, both at the party level (emergence of populist anti-elite parties) and the level of the political publics (social media platforms and political web culture). First, the findings demonstrate the return of politically disaffected voters to the ballot box. Over the last two decades, their feeling of being left behind by political decisionmakers has increasingly translated into support for anti-elite parties who draw on a rhetoric that emphasizes the distance between ordinary citizens and the political personnel. Second, whereas citizens who feel alienated from the political establishment still participate more often in demonstrations and street protests than others. They seem to have increasingly left the streets in favor of online "voice" options on the web.

\section{Conclusion}

According to much of the present literature, feelings and beliefs among many citizens of being left behind and unheard by unresponsive political decisionmakers, who lack moral integrity represent the epicenter of recent protests and discontent in democratic society. In this article, our first aim was to take a look at the prevalence of anti-establishment sentiment, i.e., negative attitudes toward political officials, and to identify which social groups are more discontented with the political elite than others as well as which social macro-contexts are associated with such sentiment. In a second step, we have focused on the consequence of discontent with politicians for political participation and explored whether citizens with more negative attitudes toward political decisionmakers have rather become politically active over time or politically apathetic.

Based on two ISSP waves for 20 contemporary democracies, we found that anti-establishment attitudes 
are not as widespread among citizens as accounts on a "populist zeitgeist" or a "silent majority" would suggest. Such attitudes are associated with certain macrostructural dynamics, since anti-establishment attitudes are more widespread among publics in countries which exhibit higher levels of public corruption and witnessed increasing levels of economic inequality. At the individual level, such attitudes are restricted to particular segments of society, since hostile feelings toward political decisionmakers are stronger among citizens in the lower ranks of society and among younger birth cohorts. Although anti-establishment sentiment has not increased among the public since the beginning of the century and throughout the Great Recession, our analysis indicates that citizens with such attitudes have increasingly turned toward voting anti-elite parties to raise their voice and now make use of online "voice" options to express their political views more frequently than in the past. We have interpreted this finding as a result of changing opportunity structures and macrostructural contexts. Thus, when anti-elitist discourse succeeds in resonating with relatively stable attitudes toward political decisionmakers in the population, these attitudes can find expression in viable modes of political action whether in the form of support for political candidates or participation in movement-based protests and digital publics.

Our study is confronted by several limitations. First, our operationalization of anti-establishment sentiment which basically relies on extracting people's (latent) evaluative attitudes from self-reported answers cannot fully satisfy "anti-establishmentness" in its emotional complexity. Indeed, our operationalization leaves the affective part of anti-establishment sentiment largely unaddressed, since affective evaluations on the basis of emotions like anger, outrage, resentment, worry, frustration, powerlessness, or even hate are not included in our measure (see Capelos \& Demertzis, 2018; Salmela \& Capelos, 2021; Salmela \& von Scheve, 2017). However, since data for such more complex measurements does not exist for cross-country comparative research, we have to rely on available datasets. Second, our study investigates anti-establishment attitudes with reference to a specific group of elites, namely established politicians. Therefore, our findings cannot be generalized to other groups of elites (e.g., media elites, intellectual elites, economic elites). Third, due to the use of a crosssectional design, we are restricted to describing correlations and cannot really conclude on causal effects of antiestablishment attitudes.

As Dalton (2004, p. 7) states, "dissatisfaction with authorities, within a democratic system, is not usually a signal for basic political change." In his landmark work, The Silent Revolution, Inglehart (1977) theorizes and demonstrates the motivation driving the rise of elitechallenging action and distrust-a growing emancipatory spirit visible in changing value orientations. Similarly, Dalton and Welzel (2014) conclude that citizens have turned toward a decidedly "assertive" posture to politics: They have become more distrustful of traditional politics and are increasingly ready to confront representatives with demands from below. Today observations of a "backlash" against liberal democracy (Inglehart \& Norris, 2019) or "reactionary politics" (Capelos \& Katsanidou, 2018) expose such earlier diagnoses as rather optimistic and hint at the socially disintegrative and regressive character of elite-challenging sentiment. Not only is such sentiment distributed unequally across social groups, it has increasingly found expression in vote choice and political online activity. Indeed, it seems that political apathy has given way to resentful activity, at least in parts.

\section{Acknowledgments}

I would like to thank Mikko Salmela for inviting me to submit a paper for this issue, Leonie Schulz for her meticulous proofreading, and Lale Akarsu and two anonymous reviewers for their valuable feedback. I acknowledge support from the Open Access Publication Program of the University of Muenster.

\section{Conflict of Interests}

The author declares no conflict of interests.

\section{Supplementary Material}

Supplementary material for this article is available online in the format provided by the author (unedited).

\section{References}

Abedi, A. (2004). Anti-political establishment parties: A comparative analysis. Routledge.

Agger, R. E., Goldstein, M. N., \& Pearl, S. A. (1961). Political cynicism: Measurement and meaning. The Journal of Politics, 23(3), 477-506.

Akkerman, A., Mudde, C., \& Zaslove, A. (2014). How populist are the people? Measuring populist attitudes in voters. Comparative Political Studies, 47(9), 1324-1353.

Anderson, C. J., \& Singer, M. M. (2008). The sensitive left and the impervious right: Multilevel models and the politics of inequality, ideology, and legitimacy in Europe. Comparative Political Studies, 41(4/5), 564-599.

Anderson, C. J., \& Tverdova, Y. V. (2003). Corruption, political allegiances and attitudes toward government in contemporary democracies. American Journal of Political Science, 47(1), 91-109.

Anduiza, E., Guinjoan, M., \& Rico, G. (2019). Populism, participation, and political equality. European Political Science Review, 11(1), 109-124.

Bakker, R., Hooghe, L., Jolly, S., Marks, G., Polk, J., Rovny, J., Steenbergen, M., \& Vachudova, M. A. (2020). 1999-2019 Chapel Hill Expert Survey trend 
file (Version 1.2) [Data set]. Chesdata. https://www. chesdata.eu/1999-2019chestrend

Barnes, S., \& Kaase, M. (1979). Political action. Mass participation in five western democracies. SAGE.

Bovens, M., \& Wille, A. (2017). Diploma democracy. Oxford University Press.

Capelos, T., \& Demertzis, N. (2018). Political action and resentful affectivity in critical times. Society \& Humanity, 42(4), 410-433.

Capelos, T., \& Katsanidou, A. (2018). Reactionary politics: Explaining the psychological roots of anti preferences in European integration and immigration debates. Political Psychology, 39(6), 1271-1288.

Celis, K., Knops, L., Van Ingelgom, V., \& Verhaegen, S. (2021). Resentment and coping with the democratic dilemma. Politics and Governance, 9(3), 237-247.

Citrin, J., \& Stocker, L. (2018). Political trust in a cynical age. Annual Review of Political Science, 21, 49-70.

Dalton, R. J. (2004). Democratic challenges, democratic choices. The erosion of democratic support in advanced industrial democracies. Oxford University Press.

Dalton, R. J. (2005). The social transformation of trust in government. International Review of Sociology, 15, 133-154.

Dalton, R. J., \& Welzel, C. (2014). The civic culture transformed. From allegiant to assertive citizens. Cambridge University Press.

Eagly, A. H., \& Chaiken, S. (1993). The psychology of attitudes. Harcourt Brace Jovanovich.

Easton, D. (1975). A re-assessment of the concept of political support. British Journal of Political Science, 5(4), 435-457.

Elsässer, L., Hense, S., \& Schäfer, A. (2020). Not just money: Unequal responsiveness in egalitarian democracies. Journal of European Public Policy. Advance online publication. https://doi.org/ 10.1080/13501763.2020.1801804

Fairbrother, M. (2014). Two multilevel modeling techniques for analyzing comparative longitudinal survey datasets. Political Science Research and Methods, 2(1), 119-140.

Ferrari, D. (2021). Perceptions, resentment, economic distress, and support for right-wing populist parties in Europe. Politics and Governance, 9(3), 274-287.

Foa, R. S., \& Mounk, Y. (2017). The signs of deconsolidation. Journal of Democracy, 28(1), 5-15.

Gallego, A. (2014). Unequal political participation worldwide. Cambridge University Press.

Gidron, N., \& Hall, P. A. (2020). Populism as a problem of social integration. Comparative Political Studies, 53(7), 1027-1059.

Gilens, M. (2012). Affluence and influence. Economic inequality and political power in America. Princeton University Press.

Grasso, M. T., Yoxon, B., Karampampas, S., \& Temple, L. (2019). Relative deprivation and inequalities in social and political activism. Acta Politica, 54, 398-429.
Inglehart, R. F. (1977). The silent revolution: Changing values and political styles among Western publics. Princeton University Press.

Inglehart, R. F., \& Norris, P. (2019). Cultural backlash. Trump, Brexit, and authoritarian populism. Cambridge University Press.

ISSP Research Group. (2012). International Social Survey Programme 2004: Citizenship I (ISSP 2004) [Data set]. https://doi.org/10.4232/1.11372

ISSP Research Group. (2016). International Social Survey Programme 2014: Citizenship II (ISSP 2014) [Data set]. https://doi.org/10.4232/1.12590

Kaltwasser, C. R., \& Van Hauwaert, S. M. (2020). The populist citizen: Empirical evidence from Europe and Latin America. European Political Science Review, 12(1), 1-18.

Kemmers, R. (2017). Channelling discontent? Non-voters, populist party voters, and their meaningful political agency. European Journal of Cultural and Political Sociology, 4(4), 381-406.

Levitsky, S., \& Ziblatt, D. (2018). How democracies die. Crown Publishing.

Lindh, A., \& McCall, L. (2020). Class position and political opinion in rich democracies. Annual Review of Sociology, 46, 419-441.

Mair, P. (2013). Ruling the void: The hollowing out of Western democracy. Verso.

Martini, S., \& Quaranta, M. (2020). Citizens and democracy in Europe: Contexts, changes and political support. Palgrave Macmillan.

Mudde, C. (2004). The populist zeitgeist. Government \& Opposition, 39(4), 541-563.

Mudde, C., \& Kaltwasser, C. R. (2017). Populism: A very short introduction. Oxford University Press.

Niemi, R. G., Craig, S. C., \& Mattei, F. (1991). Measuring internal political efficacy in the 1988 National Election Study. The American Political Science Review, 85(4), 1407-1413.

Noordzij, K., Van der Waal, J., \& De Koster, W. (2019). The educational gradient in trust in politicians in the Netherlands: A status based cultural conflict. The Sociological Quarterly, 60(3), 439-456.

OECD. (2021). OECD statistics. https://stats.oecd.org

Oesch, D. (2013). Occupational change in Europe: How technology and education transform the job structure. Oxford University Press.

Oliver, J. E., \& Rahn, W. (2016). Rise of the Trumpenvolk: Populism in the 2016 election. ANNALS of the American Academic of Political and Social Science, 667(1), 189-206.

Rahn, W. (2019). Populism in the US: The evolution of the Trump constituency. In K. A. Hawkins, R. E. Carlin, L. Littvay, \& C. R. Kaltwasser (Eds.), The ideational approach to populism. Concept, theory, and analysis (pp. 350-373). Routledge.

Rensmann, L. (2017). The noisy counter-revolution: Understanding the cultural conditions and dynamics of populist politics in Europe in the digital age. Politics 
\& Governance, 5(4), 123-135.

Rico, G., Guinjoan, M., \& Anduiza, E. (2017). The emotional underpinnings of populism: How anger and fear affect populist attitudes. Swiss Political Science Review, 23(4), 444-461.

Rooduijn, M. (2018). What unites the voter bases of populist parties? Comparing the electorates of 15 populist parties in Western Europe. European Political Science Review, 10(3), 351-368.

Rooduijn, M., van der Brug, W., \& de Lange, S. (2016). Expressing or fueling discontent? The relationship between populist voting and political discontent. Electoral Studies, 43(1), 32-40.

Rooduijn, M., van der Brug, W., de Lange, S., \& Parlevliet, J. (2017). Persuasive populism? Estimating the effect of populist messages on political cynicism. Politics \& Governance, 5(4), 136-145.

Salmela, M., \& Capelos, T. (2021). Ressentiment: A complex emotion or an emotional mechanism of psychic defences? Politics and Governance, 9(3), 191-203.

Salmela, M., \& von Scheve, C. (2017). Emotional roots of right-wing political populism. Social Science Information, 56(4), 567-595.

Schäfer, A. (2012). Consequences of social inequality for democracy in Western Europe. Zeitschrift für Vergleichende Politikwissenschaft, 6, 23-45.

Schakel, W. (2019). Unequal policy responsiveness in the Netherlands. Socio-Economic Review. Advance online publication. https://doi.org/10.1093/ser/ mwz018

\section{About the Author}

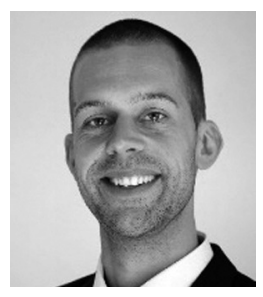

Luigi Droste is researcher and lecturer at the Institute of Sociology, University of Münster, Germany. His main research areas are political sociology, economic sociology, and quantitative data analysis.
Schattschneider, E. E. (1960). The semisovereign people: A realist's view of democracy in America. Holt, Rinehart \& Winston.

Skitka, L. J., \& Bauman, C. W. (2008). Moral conviction and political engagement. Political Psychology, 29(1), 29-54.

Sullivan, G. B. (2021). Political reactionism as affective practice: UKIP supporters and non-voters in pre-Brexit England. Politics and Governance, 9(3), 260-273.

SWIID. (2021). SWIID-The standardized world income inequality database. https://fsolt.org/swiid

Torcal, M., \& Montero, J. M. (2006). Political disaffection in contemporary democracies. Social capital, institutions, and politics. Routledge.

Transparency International. (2021). Corruption perceptions index. https://www.transparency.org/en/cpi/ 2020/index

van Ham, C., Thomassen, J., Aarts, K., \& Andeweg, R. (2017). Myth and reality of the legitimacy crisis. Explaining trends and cross-national differences in established democracies. Oxford University Press.

van Stekelenburg, J., \& Klandermans, B. (2013). The social psychology of protest. Current Sociology, 61(5/6), 886-905.

Zukin, C., Keeter, S., Andolina, M., Jenkins, K., \& Delli Carpini, M. X. (2006). A new engagement? Political participation, civic life and the changing American citizen. Oxford University Press. 